\title{
KEWENANGAN PEMERINTAH DAERAH TERHADAP HAK PENGUASAAN ATAS TANAH
}

\author{
Urip Santoso \\ Fakultas Hukum Universitas Airlangga \\ E-mail: urip_sts@yahoo.com
}

\begin{abstract}
Tenure of land that can be controlled by local government is the right to use and the right to managing the Land. The authority of local government to the land which has the status of right to use by using the land for the benefit of its duties. If the land has the right to managing statutes, the authority is planning the design and the use of land, using the land for the benefit of its duties, and handed the right of managing land to the third parties and/ or work with the third parties. Local government are not authorized to lease the right of land and the right of management to another party.
\end{abstract}

Keywords: authority, local government, tenure of land

\begin{abstract}
Abstrak
Hak penguasaan atas tanah yang dapat dikuasai oleh Pemerintah Daerah adalah Hak Pakai dan Hak Pengelolaan. Kewenangan Pemerintah Daerah terhadap tanahnya yang berstatus Hak Pakai adalah mempergunakan tanah untuk kepentingan pelaksanaan tugasnya. Kalau tanahnya berstatus Hak Pengelolaan, maka kewenangannya adalah merencanakan peruntukan dan penggunaan tanah, mempergunakan tanah untuk kepentingan pelaksanaan tugasnya, dan menyerahkan bagian-bagian tanah Hak Pengelolaan kepada pihak ketiga dan atau bekerja sama dengan pihak ketiga. Pemerintah Daerah tidak berwenang menyewakan tanah Hak Pakai dan Hak Pengelolaan kepada pihak lain.
\end{abstract}

Kata kunci: kewenangan, pemerintah daerah, hak penguasaan atas tanah

\section{Pendahuluan}

Ketentuan-ketentuan pokok tentang pertanahan di Indonesia diatur dalam UU No. 5 Tahun 1960 tentang Peraturan Dasar Pokok-pokok Agraria, LNRI Tahun 1960 No. 104 - TLNRI No. 2043, atau yang lebih dikenal dengan sebutan Undang-undang Pokok Agraria (UUPA). UUPA berlaku sejak tanggal 24 September 1960 dan sejak saat itu berlakulah Hukum Tanah Nasional. Muchsin menyatakan bahwa tujuan UUPA adalah untuk kemakmuran rakyat. Tujuan UUPA ini sesuai dengan tujuan berbangsa dan bernegara, yaitu terwujudnya kesejahteraan rakyat. ${ }^{1}$

Muchsin, “Mengenang 51 Tahun Undang-undang Pokok Agraria: Eksistensi, Regulasi, dan Konflik Agraria", J urnal Varia Peradilan Mahkamah Agung J akarta, November 2011, hlm. 5. Lihat juga Masyhud Asyhari, "Pemberdayaan Hak-Hak Rakyat atas Tanah", J urnal Hukum lus Quia lustum, 13 (7) April 2000, hlm 108-109.
Ruang lingkup agraria dalam UUPA meliputi bumi, air, ruang angkasa, dan kekayaan alam yang terkandung di dalamnya. Ruang lingkup bumi meliputi permukaan bumi (tanah), tubuh bumi, dan ruang yang ada di bawah permukaan air. Dengan demikian, tanah merupakan bagian kecil dari agraria. Tanah yang dimaksudkan disini bukan mengatur tanah dalam segala aspeknya, melainkan hanya mengatur salah satu aspeknya, yaitu tanah dalam pengertian yuridis, yang disebut hak penguasaan atas tanah. Boedi Harsono menyatakan bahwa hak penguasaan atas tanah berisi serangkaian kewenangan, kewajiban, dan atau larangan bagi pemegang haknya untuk berbuat sesuatu mengenai tanah yang dihaki. Sesuatu yang boleh, wajib, atau dilarang untuk diperbuat, yang merupakan isi hak penguasaan itulah yang menjadi kriterium atau tolok ukur 
pembeda di antara hak-hak penguasaan atas tanah yang diatur dalam hukum tanah. ${ }^{2}$ Dalam hak penguasaan atas tanah terdapat kewenangan yang dapat dilakukan, kewajiban yang harus dilakukan, dan larangan yang tidak boleh dilakukan bagi pemegang haknya.

Salah satu hak penguasaan atas tanah adalah hak menguasai Negara atas tanah. Hak menguasai Negara atas tanah diatur dalam Pasal 2 UUPA. Wewenang hak menguasai negara atas tanah dimuat dalam Pasal 2 ayat (2) UUPA, yaitu: pertama, mengatur dan menyelenggarakan peruntukan, penggunaan, persediaan, dan pemeliharaan bumi, air, dan ruang angkasa; kedua, menentukan dan mengatur hubungan-hubungan hukum antara orang-orang dengan bumi, air, dan ruang angkasa; dan ketiga, menentukan dan mengatur hubungan-hubungan hukum antara orang-orang dan perbuatan-perbuatan hukum yang mengenai bumi, air, dan ruang angkasa.

Pelaksanaan hak menguasai negara atas tanah dapat dikuasakan atau dilimpahkan kepada Pemerintah Daerah dan masyarakat-masyarakat hukum adat sekadar diperlukan dan tidak bertentangan dengan nasional menurut ketentuan-ketentuan Peraturan Pemerintah. Pernyataan ini dapat diselaraskan dengan UU No. 22 Tahun 1999 tentang Pemerintah Daerah maupun UU No. 32 Tahun 2004 tentang Pemerintahan Daerah. ${ }^{3}$ Pasal 4 ayat (1) UUPA menetapkan bahwa bersumber dari hak menguasai negara atas tanah ditentukan macam-macam hak atas permukaan bumi yang disebut tanah, yang dapat diberikan kepada dan dipunyai oleh orang-orang baik sendiri-sendiri maupun bersama-sama dengan orang lain, serta badan-badan hukum. Hak-hak atas tanah dapat diberikan kepada dan dipunyai oleh orang perorang dari warga negara Indonesia, orang asing yang berkedudukan di Indonesia, beberapa orang secara bersama-sama, badan hukum Indonesia atau badan hukum asing yang mempunyai per-

Boedi Harsono, 2007, Hukum Agraria Indonesia Sej arah Pembentukan Undang-undang Pokok Agraria, Isi, dan Pelaksanaannya, J akarta: Dj ambatan, hlm. 24.

Sri Winarsi, "Wewenang Pertanahan di Era Otonomi Daerah", J urnal Yuridika Fakultas Hukum Universitas Airlangga Surabaya, 23 (3) September 2008, hlm. 263. wakilan di Indonesia, dan badan hukum privat atau badan hukum publik. Hak-hak atas tanah yang disebutkan dalam Pasal 4 ayat (1) UUPA dijabarkan macamnya oleh Pasal 16 ayat (1) UUPA dan Pasal 53 UUPA.

Hak atas tanah adalah hak yang memberi wewenang kepada pemegang haknya untuk mempergunakan dan atau mengambil manfaat dari tanah yang dihaki. Perkataan mempergunakan mengandung pengertian bahwa hak atas tanah itu digunakan untuk kepentingan mendirikan bangunan, sedangkan perkataan mengambil manfaat mengandung pengertian bahwa hak atas tanah digunakan untuk kepentingan pertanian, perikanan, peternakan, dan perkebunan. Sistem dalam UUPA menentukan bahwa macam hak atas tanah bersifat terbuka, artinya masih terbuka peluang adanya penambahan macam hak atas tanah baru yang akan ditetapkan dengan Undang-undang. Penambahan macam hak atas tanah baru disebabkan oleh dinamika pembangunan. ${ }^{4}$

Berdasarkan subjek hukumnya, hak atas tanah dapat dimiliki atau dikuasai oleh perseorangan atau badan hukum. Subyek hukum yang berbentuk perseorangan dapat berasal dari warga negara Indonesia atau orang asing yang berkedudukan di Indonesia. Subjek hukum yang berbentuk badan hukum dapat berupa badan hukum privat atau badan hukum publik, badan hukum yang didirikan menurut hukum Indonesia dan berkedudukan di Indonesia atau badan hukum asing yang mempunyai perwakilan di Indonesia. Salah satu badan hukum yang dapat menguasai tanah adalah Pemerintah Daerah, yaitu Pemerintah Provinsi dan Pemerintah Kabupaten/ Kota.

Perseorangan dimungkinkan memperoleh atau mendapatkan hak atas tanah. Hak atas tanah tersebut tidak bersifat absolute, tetapi mempunyai fungsi sosial, seperti yang disebutkan dalam Pasal 6 UUPA. ${ }^{5}$ Dalam memperguna-

\footnotetext{
4 Urip Santoso, "Pengaturan Hak Pengelolaan", J urnal Media Hukum Fakultas Hukum UMY Yogyakarta, 15 (1) J uni 2008, hlm. 142

5 Eman, "Pengadaan Tanah Bagi Pelaksanaan Pembangunan Untuk Kepentingan Umum". J urnal Yuridika Fakultas Hukum Universitas Airlangga Surabaya, 23 (1) J anuari 2008, hlm. 52.
} 
kan tanah harus ada keseimbangan antara kepentingan pribadi dengan kepentingan umum, dalam mempergunakan tanah tidak boleh merugikan kepentingan orang lain, penggunaan harus disesuaikan dengan keadaan, sifat dari haknya, dan penggunaan tanah bermanfaat bagi pemegang haknya maupun masyarakatnya. Mencermati uarain di atas, maka tulisan ini akan membahas tentang hak penguasaan atas tanah oleh Pemerintah Daerah dan bentuk kewenangan Pemerintah Daerah dalam hak penguasaan atas tanah.

\section{Hak Penguasaan Atas Tanah oleh Pemerintah Daerah.}

Bermacam-macam hak atas tanah yang disebutkan dalam Pasal 16 ayat (1) UUPA dan Pasal 53 UUPA. Hak atas tanah yang dapat dikuasai oleh Pemerintah Daerah adalah Hak Pakai. Hak Pakai diatur dalam Pasal 41 sampai dengan Pasal 43 UUPA. Lebih lanjut tentang Hak Pakai diatur dalam Pasal 39 sampai dengan Pasal 58 Peraturan Pemerintah No. 40 Tahun 1996 tentang Hak Guna Usaha, Hak Guna Bangunan, dan Hak Pakai Atas Tanah. Pengertian Hak Pakai disebutkan dalam Pasal 41 ayat (1) UUPA, yaitu:

Hak Pakai adalah hak untuk menggunakan dan atau memungut hasil dari tanah yang dikuasai langsung oleh Negara atau tanah milik orang lain, yang memberi wewenang dan kewajiban yang ditentukan dalam keputusan pemberiannya oleh pejabat yang berwenang memberikannya atau dengan perjanjian dengan pemilik tanahnya, yang bukan perjanjian sewa menyewa atau perjanjian pengolahan tanah, segala sesuatu asal tidak bertentangan dengan jiwa dan ketentuan-ketentuan undang-undang ini.

Berdasarkan ketentuan Pasal 41 ayat (1) UUPA, Hak Pakai dapat digunakan untuk kepentingan mendirikan bangunan yaitu pada kata menggunakan, dan atau dapat digunakan untuk kepentingan pertanian, perikanan, peternakan, dan perkebunan yaitu pada kata memungut hasil dari tanah. Hak Pakai dapat berasal dari tanah Negara, atau tanah milik orang lain. Hak Pakai yang berasal dari tanah Negara terjadi dengan keputusan pemberian hak, sedangkan Hak Pakai yang berasal dari tanah Hak Milik terjadi dengan perjanjian dengan pemilik tanah.

Pasal 42 UUPA menetapkan bahwa yang dapat mempunyai hak pakai, adalah: pertama, Warga Negara Indonesia; kedua, orang asing yang berkedudukan di Indonesia; ketiga, badan hukum yang didirikan menurut hukum Indonesia dan berkedudukan di Indonesia; dan keempat, badan hukum asing yang mempunyai perwakilan di Indonesia. Dari ketentuan Pasal 42 UUPA menunjukkan bahwa tidak disebutkan secara tegas bahwa Pemerintah Daerah (Pemerintah Provinsi, Pemerintah Kabupaten/Kota) sebagai pihak yang dapat mempunyai hak pakai. Disini hanya disebutkan bahwa salah satu subjek hak pakai adalah badan hukum yang didirikan menurut hukum Indonesia dan berkedudukan di Indonesia.

Untuk pertama kali disebutkan bahwa Pemerintah Daerah sebagai subjek hak pakai, adalah dalam Pasal 1 Peraturan Menteri Agraria No. 9 Tahun 1965 tentang Pelaksanaan Konversi Hak Penguasaan Atas Tanah Negara dan Kebijaksanaan Selanjutnya, yaitu: "Jika hak penguasaan atas tanah yang diberikan kepada Departemen-departemen, Direktorat-direktorat, dan Daerah Swatantra dipergunakan untuk kepentingan instansi-instansi itu sendiri dikonversi menjadi hak pakai". Selanjutnya dalam Pasal 1 huruf a Peraturan Menteri Agraria No. 1 Tahun 1966 tentang Pendaftaran Hak Pakai dan Hak Pengelolaan dinyatakan bahwa selain Hak Milik, Hak Guna Usaha, dan Hak Guna Bangunan, maka harus pula didaftarkan menurut ketentuan-ketentuan Peraturan Pemerintah No 10 Tahun 1961, yaitu semua Hak Pakai, termasuk yang diperoleh Departemen-departemen, Direktorat-direktorat dan Daerah-daerah Swatantra sebagai dimaksud dalam Pasal 1 Peraturan Menteri Agraria No. 9 Tahun 1965".

Pasal 39 Peraturan Pemerintah No. 40 Tahun 1996 dinyatakan bahwa yang dapat mempunyai Hak Pakai, adalah Warga Negara Indonesia; Badan hukum yang didirikan menurut Hukum Indonesia dan berkedudukan di Indonesia; Departemen, Lembaga Pemerintah 
Non Departemen, dan Pemerintah Daerah; Badan-badan keagamaan dan sosial; Orang asing yang berkedudukan di Indonesia; Badan hukum asing yang mempunyai perwakilan di Indonesia; dan Perwakilan Negara asing dan perwakilan badan internasional. Berdasarkan Pasal 39 Peraturan Pemerintah No. 40 Tahun 1996, Pemerintah Daerah termasuk salah satu subjek Hak Pakai atas tanah.

Pasal 49 Peraturan Menteri Negara Agraria/ Kepala Badan Pertanahan Nasional No. 9 Tahun 1999 tentang Tata Cara Pemberian dan Pembatalan Hak Atas Tanah Negara dan Hak Pengelolaan disebutkan bahwa Hak Pakai dapat diberikan kepada: Warga Negara Indonesia; Orang asing yang berkedudukan di Indonesia; Instansi Pemerintah; Badan hukum yang didirikan menurut Hukum Indonesia dan berkedudukan di Indonesia; Badan hukum asing yang mempunyai perwakilan di Indonesia. Dalam Pasal tersebut tidak disebutkan secara tegas bahwa Pemerintah Daerah merupakan subjek Hak Pakai atas tanah. Pasal tersebut hanya menyebutkan bahwa instansi Pemerintah dapat diberikan Hak Pakai. Instansi Pemerintah yang dimaksud menurut Pasal 1 angka 1 Peraturan Kepala Badan Pertanahan Nasional Republik Indonesia No. 3 Tahun 2007 tentang Ketentuan Pelaksanaan Peraturan Presiden No. 36 Tahun 2005 tentang Pengadaan Tanah Bagi Pelaksanaan Pembangunan Untuk Kepentingan Umum Sebagaimana Telah Diubah Dengan Peraturan Presiden Nomor 65 Tahun 2006 tentang Perubahan Atas Peraturan Presiden Nomor $36 \mathrm{Ta}$ hun 2005 tentang Pengadaan Tanah Bagi Pelaksanaan Pembangunan Untuk Kepentingan Umum, adalah Lembaga Negara, Departemen, Lembaga Pemerintah Non Departemen, Pemerintah Provinsi, atau Pemerintah Kabupaten/ Kota. Dari ketentuan ini, jelaslah bahwa Pemerintah Provinsi, Pemerintah Kabupaten/ Kota sebagai Pemerintah Daerah merupakan subjek Hak Pakai atas tanah.

Selain Hak Pakai atas tanah, hak penguasaan atas tanah yang dapat dikuasai oleh Pemerintah Daerah adalah Hak Pengelolaan. Secara tersurat, UUPA tidak menyebut Hak Pengelolaan, tetapi hanya menyebut pengelolaan dalam Penjelasan Umum Angka II Nomor 2 UUPA, yaitu

Negara dapat memberikan tanah yang demikian itu kepada seseorang atau badan hukum dengan sesuatu hak menurut peruntukan dan keperluannya, misalnya Hak Milik, Hak Guna Usaha, Hak Guna Bangunan, dan Hak Pakai, atau memberikannya dalam pengelolaan (garis bawah penulis) kepada suatu badan penguasa (Departemen, J awatan, atau Daerah Swatantra) untuk digunakan bagi pelaksanaan tugasnya masing-masing

Sebelum diundangkan UUPA, terdapat Peraturan Pemerintah No. 8 Tahun 1953 tentang Penguasaan Tanah-tanah Negara. Dalam Peraturan Pemerintah ini ditetapkan bahwa penguasaan atas tanah Negara dapat diserahkan kepada Daerah Swatantra untuk menyelenggarakan kepentingan daerahnya. Hak penguasaan atas tanah Negara yang diberikan kepada Daerah Swatantra dengan berlakunya Peraturan Menteri Agraria No. 9 Tahun 1965 dapat dikonversi menjadi Hak Pengelolaan. Istilah Hak Pengelolaan muncul dalam Pasal 2 Peraturan Menteri Agraria No. 9 Tahun 1965, yaitu:

J ika tanah Negara sebagai dimaksud dalam Pasal 1, selain dipergunakan untuk kepentingan instansi-instansi itu sendiri, dimaksudkan juga untuk dapat diberikan dengan sesuatu hak kepada pihak ketiga, maka hak penguasaan tersebut di atas dikonversi menjadi Hak Pengelolaan (garis bawah penulis) sebagai dimaksud dalam Pasal 5 dan 6, yang berlangsung selama tanah tersebut dipergunakan untuk keperluan itu oleh instansi yang bersangkutan

Berdasarkan Peraturan Menteri Agraria No. 9 Tahun 1965 tercipta jenis hak baru yang disebut Hak Pengelolaan. Hak Pengelolaan berasal dari konversi hak penguasaan atas tanah Negara. Menurut Supriadi, Hak Pengelolaan bukanlah nama yang diberikan oleh UUPA. Namun demikian, Hak Pengelolaan sebenarnya berasal dari terjemahan Bahasa Belanda, yang berasal dari kata Beheersrecht, artinya hak 
penguasaan. ${ }^{6}$ Hak penguasaan diatur dalam Peraturan Pemerintah No. 8 Tahun 1953 Pasal 1 Peraturan Menteri Agraria No. 1 Tahun 1966 mewajibkan kepada Daerah Swatantra untuk mendaftarkan Hak Pengelolaannya kepada Kantor Pendaftaran Tanah melalui mekanisme penegasan konversi. Dalam perkembangannya, Pasal 9 Peraturan Pemerintah No. 24 Tahun 1997 tentang Pendaftaran Tanah menetapkan bahwa Hak Pengelolaan termasuk salah satu obyek pendaftaran tanah. ${ }^{7}$

Pengertian Hak Pengelolaan dinyatakan dalam Pasal 1 angka 2 Peraturan Pemerintah No. 40 Tahun 1996 jo Pasal 1 angka 4 Peraturan Pemerintah No. 24 Tahun 1997, yaitu Hak Pengelolaan adalah hak menguasai negara yang kewenangan pelaksanaannya sebagian dilimpahkan kepada pemegangnya". Pengertian yang lebih lengkap tentang Hak Pengelolaan dinyatakan dalam pasal 2 ayat (3) Undangundang No. 20 Tahun 2000 tentang Perubahan Atas Undang-undang Nomor 21 Tahun 1997 tentang Bea Perolehan Hak Atas Tanah dan Bangunan jo Pasal 1 Peraturan Pemerintah No. 112 Tahun 2000 tentang Pengenaan Bea Perolehan Hak Atas Tanah dan Bangunan Karena Pemberian Hak Pengelolaan, yaitu "Hak Pengelolaan adalah hak menguasai dari Negara atas tanah yang kewenangan pelaksanaannya sebagian dilimpahkan kepada pemegang haknya untuk merencanakan peruntukan dan penggunaan tanah, menggunakan tanah untuk keperluan pelaksanaan tugasnya, menyerahkan bagian-bagian tanah Hak Pengelolaan kepada pihak ketiga dan atau bekerja sama dengan pihak ketiga.

Ketentuan-ketentuan yang menunjukkan bahwa Pemerintah Daerah dapat mempunyai tanah Hak Pengelolaan, yaitu pertama, Pasal 5 Peraturan Menteri Agraria No. 9 Tahun 1965 di mana Hak Pengelolaan dapat diberikan kepada Departemen, Direktorat, dan Daerah Swatantra; kedua, Pasal 1 huruf b Peraturan Menteri

Supriadi, 2007, Hukum Agraria, J akarta: Sinar Grafika, hlm. 148.

Lihat dan perbandingkan dengan Sukirno, "Perlindungan Hukum Masyarakat Hukum Adat", J urnal MasaIah-Masalah Hukum Fakultas Hukum UNDIP Semarang, 37 (2) J uni 2008, hlm. 135-140
Agraria No. 1 Tahun 1966 dimana Hak Pengelolaan dapat diberikan kepada Departemen, Direktorat, dan Daerah Swatantra; ketiga, Pasal 5 dan Pasal 6 Peraturan Menteri Dalam Negeri No. 5 Tahun 1974 tentang Ketentuanketentuan Mengenai Penyediaan dan Pemberian Tanah Untuk Keperluan Perusahaan dimana Hak Pengelolaan dapat diberikan kepada perusahaan pembangunan perumahan yang seluruh modalnya berasal dari Pemerintah dan/ atau Pemerintah Daerah; keempat, Pasal 2 Peraturan Pemerintah No. 36 Tahun 1997 tentang Pengenaan Bea Perolehan Hak Atas Tanah dan Bangunan Karena Pemberian Hak Pengelolaan dimana penerima Hak Pengelolaan adalah Departemen, Lembaga Pemerintah Non Departemen, Pemerintah Daerah Tingkat I, Pemerintah Daerah Tingkat II, Lembaga Pemerintah lainnya, dan Perusahaan Umum (Perum) Pembangunan Perumahan Nasional (Perumnas); Kelima, Pasal 67 Peraturan Menteri Negara Agraria/ Kepala Badan Pertanahan Nasional No. 9 Tahun 1999. Adapun badan-badan hukum yang dapat diberikan Hak Pengelolaan, adalah Instansi Pemerintah termasuk Pemerintah Daerah, Badan Usaha Milik Negara (BUMN), Badan Usaha Milik Daerah (BUMD), PT Persero, Badan Otorita dan Badan-badan hukum Pemerintah lainnya yang ditunjuk oleh Pemerintah.

Eman menyatakan bahwa subyek atau pemegang Hak Pengelolaan adalah sebatas pada badan hukum Pemerintah baik yang bergerak dalam pelayanan publik (peme-rintahan) atau yang bergeral dalam bidang bisnis, seperti Badan Usaha Milik Negara/Badan Usaha Milik Daerah, PT Persero, badan hukum swasta tidak mendapatkan peluang untuk berperan serta sebagai subyek atau pemegang Hak Pengelolaan. ${ }^{8}$ Dalam peraturan perundangan di bidang pertanahan diatur cara perolehan tanah oleh seseorang atau badan hukum, yaitu pertama, Pemberian hak dimana seseorang atau badan hukum memperoleh hak penguasaan atas tanah yang berasal dari tanah Negara me-

\footnotetext{
Eman Ramelan, "Hak Pengelolaan Setelah Berlakunya Peraturan Menteri Negara Agraria/Kepala Badan Pertanahan Nasional No. 9 Tahun 1999", J urnal Yuridika Fakultas Hukum Universitas Airlangga Surabaya, 15 (3) J uni 2006, hlm. 196.
} 
Ialui permohonan pemberian hak; kedua, penegasan konversi dimana seseorang atau badan hukum memperoleh hak penguasaan atas tanah melalui perubahan hak (konversi) dari status hak atas tanah menurut hukum yang lama sebelum berlakunya UUPA menjadi hak atas tanah menurut UUPA; ketiga, Beralihnya hak dimana seseorang memperoleh hak penguasaan atas tanah melalui pewarisan dari pewaris; keempat, Pemindahan hak dimana seseorang atau badan hukum memperoleh hak penguasaan atas tanah melalui pemindahan hak dengan cara jual beli, tukar menukar, hibah, pemasukan dalam modal perusahaan atau lelang; kelima, Perjanjian penggunaan tanah dimana seseorang atau badan hukum memperoleh Hak Guna Bangunan atau Hak Pakai melalui perjanjian penggunaan tanah dengan pemegang Hak Pengelolaan; keenam, Perubahan hak dimana seseorang memperoleh Hak Milik melalui perubahan hak yang berasal dari Hak Guna Bangunan, perubahan Hak Guna Bangunan menjadi Hak Pakai, atau badan hukum memperoleh Hak Guna Bangunan melalui perubahan hak yang berasal dari Hak Milik.

Ada 2 (dua) cara perolehan Hak Pakai atau Hak Pengelolaan oleh Pemerintah Daerah, yaitu penegasan konversi dan pemberian hak. Konversi adalah perubahan status hak atas tanah menurut hukum yang lama sebelum berlakunya UUPA, yaitu hak atas tanah yang tunduk pada hukum barat, hukum adat, dan Daerah Swatantra menjadi hak atas tanah menurut UUPA. Perolehan Hak Pakai dan Hak PengeIolaan oleh Pemerintah Daerah melalui penegasan konversi diatur dalam Peraturan Menteri Agraria No. 9 Tahun 1965. Berdasarkan Peraturan Menteri Agraria No. 9 Tahun 1965, Pemerintah Daerah (Daerah Swatantra) berkewajiban mendaftarkan konversi Hak Pakai dan Hak Pengelolaan yang berasal dari hak penguasaan atas tanah Negara kepada Kantor Pendaftaran Tanah setempat. Berkaitan dengan perolehan Hak Pengelolaan melalui konversi, Boedi Harsono menyatakan bahwa

“Menurut Peraturan Menteri Agraria No. 9 Tahun 1965, Hak Pengelolaan yang pertama-tama ada pada waktu mulai berlakunya UUPA adalah yang berasal dari konversi hak penguasaan atau hak beheer, yaitu yang tanahnya selain dipergunakan untuk kepentingan instansi yang bersangkutan, dimaksudkan juga untuk dapat diberikan dengan sesuatu hak kepada pihak ketiga. Hak Pengelolaan yang berasal dari konversi tersebut berlangsung selama tanahnya dipergunakan untuk keperluan itu. Pelaksanaan konversi itu diselenggarakan oleh Kepala Kantor Pendaftaran Tanah yang bersangkutan dan jika tanahnya belum didaftar di Kantor Pendaftaran Tanah baru diselenggarakan setelah pemegang haknya datang mendaftarkannya. ${ }^{9}$

Melalui penegasan konversi, hak penguasaan atas tanah negara yang dipunyai oleh Pemerintah Daerah (Daerah Swatantra) diubah haknya menjadi Hak Pakai atau Hak Pengelolaan. Hak penguasaan atas tanah negara yang tanahnya dipergunakan untuk kepentingannya sendiri oleh Pemerintah dikonversi menjadi Hak Pakai, sedangkan hak penguasaan atas tanah Negara yang tanahnya disamping dipergunakan untuk kepentingannya sendiri oleh Pemerintah Daerah juga untuk dapat diberikan dengan sesuatu hak kepada pihak ketiga oleh Pemerintah Daerah dikonversi menjadi Hak Pengelolaan. Hak Pakai dan Hak Pengelolaan ini lahir setelah hak penguasaan atas tanah Negara didaftarkan ke Kantor Pendaftaran Tanah dan diterbitkan sertifikat Hak Pakai atau Hak Pengeloaan sebagai tanda bukti haknya.

Pemberian hak menurut Pasal 1 ayat (8) Peraturan Menteri Negara Agraria/ Kepala Badan Pertanahan Nasional No. 9 Tahun 1999, adalah penetapan Pemerintah yang memberikan sesuatu hak atas tanah Negara, perpanjangan jangka waktu hak, pembaharuan hak, perubahan hak, termasuk pemberian hak di atas Hak Pengelolaan. Bentuk penetapan Pemerintah dalam pemberian hak berupa Surat Keputusan yang diterbitkan oleh Kepala Badan Pertana-han Nasional Republik Indonesia, atau pejabat Badan Pertanahan Nasional Republik Indonesia yang diberikan pelimpahan kewenangan untuk memberikan hak atas tanah. Da-

$9 \quad$ Boedi Harsono, op.cit., hlm. $325-326$. 
Iam pemberian hak ini, Hak Pakai atau Hak Pengelolaan diperoleh berasal dari tanah Negara atau tanah yang dikuasai langsung oleh Negara yang dimohonkan oleh Pemerintah Daerah. Ketentuan tentang perolehan Hak Pakai atau Hak Pengelolaan melalui pemberian hak semula diatur oleh Peraturan Menteri Dalam Negeri No. 5 Tahun 1973, kemudian dinyatakan tidak berlaku lagi oleh Peraturan Menteri Negara Agraria/ Kepala Badan Pertanahan Nasional No. 9 Tahun 1999.

Secara garis besar, perolehan Hak Pakai atau Hak Pengelolaan oleh Pemerintah Daerah melalui pemberian hak, yaitu Pemerintah Daerah mengajukan permohonan Hak Pakai atau Hak Pengelolaan kepada Kepala Badan Pertanahan Nasional Republik Indonesia melalui Kepala Kantor Pertanahan Kabupaten/ Kota setempat. Kalau semua persyaratan yang ditentukan dalam permohonan pemberian hak dipenuhi oleh Pemerintah Daerah, maka Kepala Badan Pertanahan Nasional Republik Indonesia menerbitkan Surat Keputusan Pemberian Hak Pakai atau Hak Pengelolaan. Surat Keputusan Pemberian Hak Pakai atau Hak Pengelolaan wajib didaftarkan oleh Pemerintah Daerah kepada Kepala Kantor Pertanahan Kabupaten/ Kota setempat untuk diterbitkan Sertifikat Hak Pakai atau Hak Pengelolaan sebagai tanda bukti haknya. Pendaftaran Surat Keputusan Pemberian Hak Pakai atau Hak Pengeloolaan oleh Pemerintah Daerah kepada Kepala Kantor Pertanahan Kabupaten/Kota setempat menandai lahirnya Hak Pakai atau Hak Pengelolaan.

Maksud diterbitkan sertifikat adalah agar pemegang hak dengan mudah dapat membuktikan bahwa dirinya sebagai pemegang haknya, mendapatkan jaminan kepastian hukum dan perlindungan hukum. Sertifikat diterbitkan untuk kepentingan pemegang hak yang bersangkutan sesuai dengan data fisik dan data yuridis yang telah didaftar dalam buku tanah. ${ }^{10}$

10 Urip Santoso, "Sertipikat Sebagai Tanda Bukti Hak Atas Tanah", J urnal Era Hukum Fakultas Hukum Universitas Tarumanagara Jakarta, 15 (1) September 2007, hlm. 682

\section{Bentuk Kewenangan Pemerintah Daerah da- lam Hak Penguasaan Atas Tanah.}

Pemberian sesuatu hak penguasaan atas tanah kepada seseorang atau badan hukum dilekati dengan wewenang yang ada pada hak penguasaan atas tanah tersebut. Mengenai wewenang dinyatakan oleh Sumardji, yaitu wewenang didiskripsikan sebagai kekuasaan hukum (rechtsmacht). Jadi dalam konsep hukum publik, wewenang berkaitan dengan kekuasaan. Oleh karena itu, konsep wewenang merupakan konsep dalam hukum publik. ${ }^{11} \mathrm{Yu}$ dhi Setiawan dan Boedi Djatmiko $\mathrm{H}$ menyatakan bahwa wewenang atau kompetensi diartikan sebagai suatu hak untuk bertindak atau suatu kekuasaan untuk membuat keputusan, memerintah atau melimpahkan tanggung jawab kepada orang lain. Kewenangan juga diartikan sebagai hak atau kekuasaan yang dipunyai untuk mendapatkan sesuatu. ${ }^{12}$

Wewenang tersebut menjadi dasar bagi pemegang hak penguasaan atas tanah untuk mempergunakan tanah menurut keperluan dan peruntukannya. Status tanah yang dapat dikuasai oleh Pemerintah Daerah adalah Hak Pakai dan Hak Pengelolaan. Hak Pakai dan Hak Pengelolaan sebagai bagian dari hak penguasaan atas tanah di dalamnya dimuat wewenang, kewajiban, dan larangan bagi Pemerintah Daerah. Pemberian Hak Pakai dan Hak Pengelolaan kepada Pemerintah Daerah dilekati dengan wewenang yang ada pada kedua hak tersebut.

Wewenang merupakan bagian yang sangat penting dalam hukum tata pemerintahan (hukum administrasi), karena pemerintahan baru dapat menjalankan fungsinya atas dasar wewenang yang diperoleh. Dalam hal ini, wewenang merupakan kemampuan bertindak yang diberikan kepada subjek hukum berdasar-

11 Sumardji, “Dasar dan Ruang Lingkup Wewenang Dalam Hak Pengelolaan", Majalah Yuridika Fakultas Hukum Universitas Airlangga Surabaya, 21 (3) Mei 2006, hlm. 246.

12 Yudhi Setiawan dan Boedi Djatmiko H, "Pembatalan sertipikat Hak Atas Tanah Oleh Pengadilan Tata Usaha Negara Dengan Alasan Cacat Yuridis Dalam Aspek Wewenang, Jurnal Era Hukum Fakultas Hukum Universitas Tarumanagara, Jakarta, 15 (3) Mei 2008, hlm. 887. 
kan undang-undang untuk melakukan suatu hubungan hukum dan perbuatan hukum.

Sudikno Mertokusumo menyatakan bahwa wewenang yang dipunyai pemegang hak atas tanah dibagi menjadi 2 (dua). Pertama, wewenang umum. Wewenang yang bersifat umum yaitu pemegang hak atas tanah mempunyai wewenang untuk menggunakan tanahnya, termasuk juga tubuh bumi dan air dan ruang yang ada di atasnya sekadar diperlukan untuk kepentingan yang langsung behrubungan dengan penggunaan tanah itu dalam batas-batas menurut UUPA dan peraturan-peraturan hukum lain yang lebih tinggi (Pasal 4 ayat (2) UUPA). Kedua, wewenang khusus. Wewenang yang bersifat khusus yaitu pemegang hak atas tanah mempunyai wewenang untuk menggunakan tanahnya sesuai dengan macam hak atas tanahnya, misalnya wewenang pada tanah Hak Milik adalah dapat untuk kepentingan pertanian dan atau mendirikan bangunan, wewenang pada Hak Guna Bangunan adalah menggunakan tanahnya hanya untuk mendirikan dan mempunyai bangunan atas tanah yang bukan miliknya, wewenang pada Hak Guna Usaha adalah menggunakan tanahnya hanya untuk kepentingan perusahaan di bidang pertanian, perikanan, peternakan, dan perkebunan. ${ }^{13}$

Kalau tanah yang dikuasai oleh Pemerintah Daerah berstatus Hak Pakai, maka kewenangan terhadap tanahnya adalah mempergunakan tanah Hak Pakai tersebut untuk kepentingan pelaksanaan tugasnya. Kalau tanah Hak Pakai tersebut tidak lagi dipergunakan untuk kepentingan pelaksanaan tugasnya, maka Hak Pakai tersebut menjadi hapus dan tanahnya kembali menjadi tanah Negara atau tanah yang dikuasai langsung oleh Negara.

Ketentuan-ketentuan tentang Hak Pakai yang dikuasai oleh Pemerintah Daerah, dapat dilihat dalam beberapa aspek. Pertama, aspek penggunaan tanahnya, Hak Pakai ini dipergunakan untuk kepentingan pelaksanaan tugas Pemerintah Daerah; kedua, aspek masa penguasaan tanahnya, Hak Pakai ini tidak ber-

13 Sudikno Mertokusumo, 1988, Hukum dan Politik Agraria, Jakarta: Universitas Terbuka-Karunika, hlm. 45. jangka waktu tertentu, melainkan berlaku selama tanahnya dipergunakan untuk kepentingan pelaksanaan tugasnya; ketiga, aspek sifatnya, Hak Pakai ini bersifat right to use, yaitu haknya hanya mempergunakan tanah untuk kepentingan pelaksanaan tugasnya, tidak right of dispossal, yaitu tidak berhak mengalihkan atau menjadikan jaminan utang; keempat, aspek peralihan haknya, Hak Pakai ini tidak dapat dialihkan dalam bentuk apapun kepada pihak lain melalui jual beli, tukar menukar, hibah, pemasukan dalam perusahaan, atau lelang; kelima, aspek pembebanan haknya, Hak Pakai ini tidak dapat dijadikan jaminan utang dengan dibebani Hak Tanggungan; keenam, Pihak lain yang memerlukan tanah Hak Pakai ini ditempuh melalui pelepasan atau penyerahan Hak Pakai oleh Pemerintah Daerah setelah mendapatkan persetujuan dari Dewan Perwakilan Rakyat Daerah (DPRD); dan ketujuh, hak Pakai ini tidak dapat disewakan oleh Pemerintah Daerah kepada pihak lain karena tanah yang dapat disewakan hanya tanah yang berstatus Hak Milik.

Kalau tanah yang dikuasai oleh Pemerintah Daerah berstatus Hak Pengelolaan, maka Pemerintah Daerah mempunyai beberapa wewenang. Pertama, merencanakan peruntukan dan penggunaan tanah. Pemerintah Daerah sebagai pemegang Hak Pengelolaan mempunyai wewenang berupa merencanakan peruntukan dan penggunaan tanah untuk keperluan perumahan, industri, perdagangan, pertokoan, atau perkantoran. Peruntukan dan penggunaan tanah yang direncanakan oleh Pemerintah Daerah berpedoman pada Rencana Tata Ruang Wilayah (RTRW) Kabupaten/ Kota yang ditetapkan dengan Peraturan Daerah Kabupaten/ Kota. Kedua, menggunakan tanah untuk keperluan pelaksanaan tugasnya. Pemerintah Daerah sebagai pemegang Hak Pengelolaan mempunyai wewenang untuk mempergunakan tanah Hak Pengelolaan untuk keperluan pelaksanaan tugasnya, misalnya perumahan, industri, perdagangan, pertokoan, atau perkantoran. Ketiga, menyerahkan bagian-bagian tanah Hak Pengelolaan kepada pihak ketiga dan atau bekerja sama dengan pihak ketiga. Pemerintah 
Daerah sebagai pemegang Hak Pengelolaan tidak berwenang menyewakan bagian-bagian tanah Hak Pengelolaan kepada pihak ketiga. Kalau pemegang Hak Pengelolaan menyewakan bagian-bagian tanah Hak Pengelolaan kepada pihak ketiga, maka bertentangan dengan ketentuan Pasal 44 UUPA, yaitu tanah yang dapat disewakan kepada pihak lain hanya tanah yang berstatus Hak Milik.

Wewenang yang dimiliki oleh Pemerintah Daerah sebagai pemegang Hak Pengelolaan adalah menyerahkan bagian-bagian tanah Hak Pengelolaan kepada pihak ketiga dalam bentuk Hak Guna Bangunan, Hak Pakai, atau Hak Milik. Bagian-bagian tanah Hak Pengelolaan yang diserahkan oleh pemegang haknya kepada pihak ketiga harus sudah bersertipikat Hak Pengelolaan. Dengan telah bersertipikat Hak Pengelolaan, maka pemegang Hak Pengelolaan sudah mempunyai wewenang untuk mengadakan hubungan hukum dengan pihak ketiga. Maria S.W. Sumardjono menyatakan bahwa untuk memperoleh Hak Guna Bangunan di atas Hak Pengelolaan, pihak ketiga harus memperoleh persetujuan dari pemegang Hak Pengelolaan yang dimuat dalam Perjanjian Penyerahan, Penggunaan, dan Pengurusan Hak Atas Tanah, karena perjanjian itu merupakan alas hak pemberian Hak Guna Bangunan di atas Hak Pengelolaan. ${ }^{14}$

Pihak ketiga yang memperoleh Hak Guna Bangunan atau Hak Pakai yang berasal dari bagian-bagian tanah Hak Pengelolaan melalui Perjanjian Penggunaan Tanah antara Pemerintah Daerah sebagai pemegang Hak Pengelolaan dengan pihak ketiga. Perjanjian Penggunaan Tanah dapat dibuat dengan akta notaris atau akta di bawah tangan. Ketentuan tentang Perjanjian Penggunaan Tanah diatur dalam Pasal 4 ayat (2) Peraturan Menteri Negara Agraria/Kepala Badan Pertanahan Nasional No. 9 Tahun 1999, yaitu: "Dalam hal tanah yang dimohon merupakan tanah Hak Pengelolaan, pemohon harus terlebih dahulu memperoleh pe-

14 Maria S.W. Sumardjono, "Hak Pengelolaan: Perkembangan, Regulasi, dan Implementasinya", J urnal Mimbar Hukum Fakultas Hukum UGM Yogyakarta, Edisi Khusus September 2007, hlm. 34. nunjukan berupa perjanjian penggunaan tanah dari pemegang Hak Pengelolaan".

Pihak ketiga dapat memperoleh Hak Guna Bangunan atau Hak Pakai yang berasal dari tanah Hak Pengelolaan melalui perjanjian Build, Operate, and Transfer (BOT). Maria S.W. Sumardjono mendefinisikan perjanjian BOT, yaitu:

"Perjanjian antara dua pihak, dimana pihak pertama menyerahkan penggunaan tanahnya untuk didirikan suatu bangunan di atasnya oleh pihak kedua, dan pihak kedua berhak mengoperasikan atau mengelola bangunan tersebut dalam jangka waktu tertentu, dengan memberikan fee atau tanpa fee kepada pihak pertama, dan pihak kedua wajib mengembalikan tanah beserta bangunan di atasnya dalam keadaan dapat dan siap dioperasikan kepada pihak pertama setelah jangka waktu operasional berakhir". ${ }^{15}$

Keberadaan Build, Operate, and Transfer (BOT) didasarkan oleh keterbatasan kemampuan Pemerintah atau Pemerintah Daerah dalam merealisasikan proyek pembangunan infrastruktur disebabkan oleh sangat terbatasnya dana Anggaran Pendapatan dan Belanja Negara (APBN) atau Anggaran Pendapatan dan Belanja Daerah (APBD). Salah satu alternatif pembiayaan proyek yang dapat dilakukan adalah dengan mengundang pihak swasta untuk berpartisipasi dalam pengadaan proyek Pemerintah dengan sistem Build, Operate, and Transfer (BOT). Dalam perjanjian Build, Operate, and Transfer (BOT), Pemerintah Daerah menyerahkan tanah Hak Pengelolaannya kepada pihak ketiga untuk diterbitkan Hak Guna Bangunan atau Hak Pakai atas nama pihak ketiga atau pihak ketiga mendapatkan Hak Guna Bangunan atau Hak Pakai atas tanah Hak Pengelolaan. Pihak ketiga menanggung semua biaya untuk pembangunan gedung. Pihak ketiga berhak mengoperasionalkan gedung selama jangka waktu tertentu yang disepakati oleh kedua belah pihak dan mengambil seluruh atau sebagian keuntungan. Pada masa akhir perjanjian

15 Maria S.W. Sumardjono, 2008, Tanah Dalam Perspektif Hak Ekonomi, Sosial, dan Budaya, Jakarta: Penerbit Buku Kompas, hlm. 208. 
Build, Operate, and Transfer (BOT) pihak ketiga menyerahkan gedung beserta sarana dan prasarananya kepada Pemerintah Daerah. Perjanjian Build, Operate, and Transfer (BOT) dibuat dengan akta notariil yang di dalamnya dimuat hak, kewajiban, dan larangan bagi Pemerintah Daerah dan pihak ketiga.

Diperolehnya Hak Guna Bangunan atau Hak Pakai atas tanah Hak Pengelolaan oleh pihak ketiga melalui Perjanjian Penggunaan Tanah, atau Perjanjian Build, Operate, and Transfer (BOT) tidak memutuskan hubungan hukum antara Pemerintah Daerah sebagai pemegang Hak Pengelolaan dengan tanahnya. Setiap pemindahan Hak Guna Bangunan atau Hak Pakai kepada pihak lain maupun pembebanan Hak Guna Bangunan atau Hak Pakai dengan Hak Tanggungan harus mendapatkan persetujuan tertulis terlebih dahulu dari $\mathrm{Pe}$ merintah Daerah sebagai pemegang Hak Pengelolaan.

Pihak ketiga yang memperoleh Hak Milik yang berasal dari tanah Hak Pengelolaan Pemerintah Daerah ditempuh melalui pelepasan atau penyerahan bagian-bagian tanah Hak Pengelolaan oleh Pemerintah Daerah setelah mendapatkan persetujuan dari Dewan Perwakilan Rakyat Daerah (DPRD). Pelepasan atau penyerahan bagian-bagian tanah Hak PengeIolaan untuk kepentingan pihak ketiga dapat dibuat dengan akta notaris atau akta dibawah tangan. Pelepasan atau penyerahan bagian-bagian tanah Hak Pengelolaan dengan atau tanpa ganti kerugian oleh pihak ketiga. Dengan atau tanpa ganti kerugian sesuai dengan kesepakatan antara Pemerintah Daerah sebagai pemegang Hak Pengelolaan dengan pihak ketiga. Dengan pelepasan atau penyerahan bagianbagian tanah Hak Pengelolaan, maka Hak Pengelolaan menjadi hapus dan berkaibat terputus untuk selama-lamanya hubungan hukum antara Pemerintah Daerah sebagai pemegang Hak Pengelolaan dengan tanahnya.

\section{Penutup \\ Simpulan}

Pemberian hak penguasaan atas tanah kepada seseorang atau badan hukum dilekati dengan wewenang, kewajiban, dan larangan bagi pihak yang memperoleh hak penguasaan atas tanah tersebut. Wewenang, kewajiban, dan larangan berkaitan dengan penguasaan, penggunaan, peralihan, dan pembebanan hak.

Hak penguasaan atas tanah yang dapat dikuasai oleh Pemerintah Daerah adalah Hak Pakai dan Hak Pengelolaan. Hak Pakai dan Hak Pengelolaan dapat diperoleh Pemerintah Daerah melalui penegasan konversi yang berasal dari hak penguasaan atas tanah tanah Negara, atau melalui pemberian hak yang berasal dari tanah Negara. Sebagai tanda bukti haknya diterbitkan Sertifikat Hak Pakai atau Hak PengeIolaan oleh Kantor Pertanahan Kabupaten/Kota.

Wewenang Pemerintah Daerah terhadap Hak Pakainya adalah mempergunakan tanah Hak Pakai untuk kepentingan pelaksanaan tugasnya. Wewenang Pemerintah Daerah terhadap Hak Pengelolaannya adalah merencanakan peruntukan dan penggunaan tanah, mempergunakan tanah untuk kepentingan pelaksanaan tugasnya, dan menyerahkan bagian-bagian tanah Hak Pengelolaan kepada pihak ketiga dan atau bekerja sama dengan pihak ketiga. Pemerintah Daerah tidak diperbolehkan menyewakan tanah Hak Pakai atau Hak Pengelolaan kepada pihak ketiga karena hal ini bertentangan dengan ketentuan Pasal 44 UUPA. Tanah yang dapat disewakan kepada pihak lain hanya tanah yang berstatus Hak Milik.

\section{Daftar Pustaka}

Asyhari, Masyhud. "Pemberdayaan Hak-Hak Rakyat atas Tanah". Jurnal Hukum lus Quia lustum, Vol. 13 No. 7 April 2000;

Eman, Ramelan. "Pengadaan Tanah Bagi Pelaksanaan Pembangunan Untuk Kepentingan Umum". Jurnal Yuridika Vol. 23 No. 1 J anuari 2008. FH UNAIR Surabaya;

Harsono, Boedi. 2007. Hukum Agraria Indonesia Sejarah Pembentukan Undang-undang Pokok Agraria, Isi, dan Pelaksanaannya. J akarta: Djambatan;

Mertokusumo, Sudikno. 1988. Hukum dan Politik Agraria. Jakarta: Universitas Terbuka-Karunika; 
Muchsin. "Mengenang 51 Tahun Undang-undang Pokok Agraria: Eksistensi, Regulasi, dan Konflik Agraria". Jurnal Varia Peradilan, Novem-ber 2011

Ramelan, Eman. "Hak Pengelolaan Setelah Berlakunya Peraturan Menteri Negara Agraria/ Kepala Badan Pertanahan Nasional No. 9 Tahun 1999". Jurnal Yuridika Vol. 15 No. 3 J uni 2006. FH UNAIR Surabaya;

Santoso, Urip "Pengaturan Hak Pengelolaan", Jurnal Media Hukum Vol. 15 No. 1 J uni 2008. Fakultas Hukum UMY Yogyakarta;

Santoso, Urip. "Sertipikat Sebagai Tanda Bukti Hak Atas Tanah". Jurnal Era Hukum, Vol. 15 No. 1 September 2007. FH Universitas Tarumanagara J akarta;

Setiawan, Yudhi. dan Boedi Djatmiko $\mathrm{H}$. "Pembatalan sertipikat Hak Atas Tanah Oleh Pengadilan Tata Usaha Negara Dengan Alasan Cacat Yuridis Dalam Aspek Wewenang". Jurnal Era Hukum Jakarta, Vol. 15 No. 3 Mei 2008. FH Universitas Tarumanagara;
Sukirno. "Perlindungan Hukum Masyarakat Hukum Adat". Jurnal Masalah-Masalah Hukum Vol. 37 No. 2 J uni 2008. FH UNDIP Semarang,

Sumardji. "Dasar dan Ruang Lingkup Wewenang Dalam Hak Pengelolaan". Majalah Yuridika, Vol. 21 No. 3 Mei 2006. FH UNAIR Surabaya;

Sumardjono, Maria S.W. "Hak Pengelolaan: Perkembangan, Regulasi, dan Implementasinya". Jurnal Mimbar Hukum Edisi Khusus September 2007. FH UGM Yogyakarta;

Sumardjono, Maria S.W. 2008. Tanah Dalam Perspektif Hak Ekonomi, Sosial, dan Budaya. J akarta: Penerbit Buku Kompas;

Supriadi. 2007. Hukum Agraria. Jakarta: Sinar Grafika;

Winarsi, Sri. "Wewenang Pertanahan di Era Otonomi Daerah", Jurnal Yuridika Vol. 23 No. 3 September 2008; FH UNAIR Surabaya. 